\title{
Experiencia de lucha y formas de estructuración gremial de los trabajadores de la madera de la ciudad de Buenos Aires, 1915-1930
}

\author{
Struggle experience and woodworker's forms of union organization in \\ Buenos Aires city, 1915-1930
}

Walter L. Koppmann ${ }^{*}$

\begin{abstract}
Resumen: Este artículo expone la experiencia de lucha y las formas de organización sindical de los trabajadores de la madera de la ciudad de Buenos Aires, durante las primeras décadas del siglo XX. Mediante el estudio de caso, se relevan las distintas etapas que marcaron la estructuración gremial en relación con las formas del proceso de trabajo y cómo esta última esfera condicionaba una morfología específica del organismo sindical. A su vez, se estudia el papel central que jugaron las corrientes de izquierda dentro de la conformación de la clase y de la organización en los lugares de trabajo.
\end{abstract}

Palabras clave: organización sindical; trabajadores de la madera; proceso de trabajo; corrientes de izquierda

\begin{abstract}
The aim of this paper is to present the different forms of labor struggle that the woodworkers unions of Buenos Aires adopted during the first decades of the $20^{\text {th }}$ century. We are going to try to determine the way in which the production process influenced the morphology of the union body. In addition we are going to analyze the central role of the left currents in the making of the working class and in the organization of the workplaces.
\end{abstract}

Keywords: union body; woodworkers; production process; lefts

Recibido:

Aceptado:

\footnotetext{
*Argentino. Becario doctoral de la Facultad de Filosofía y Letras (FFyL), Universidad de Buenos Aires (UBA), proyecto UBACyT 2014-2017, "Experiencias de organización gremial y militancia en los sitios de trabajo: un análisis de la izquierda en la Argentina, 1905-1945”, bajo la dirección del Dr. Hernán Camarero. Mail: walter.koppmann@gmail.com
} 
El objetivo principal de este artículo es presentar los resultados de nuestra investigación sobre la rama de la madera de la ciudad de Buenos Aires, entre 1915 y 1930, poniendo el foco en el proceso de trabajo, las formas de organización y las luchas obreras. La elección de este sector productivo no fue casual. Desde el punto de vista del incipiente proceso de industrialización que comenzaba a asomar hacia 1920, la industria maderera se muestra como un laboratorio que concentraba las tendencias más fundamentales y contradictorias del despliegue capitalista. En este punto, son aún escasas las contribuciones sobre los avatares del movimiento obrero en los orígenes del desarrollo industrial argentino en relación con la trayectoria de las culturas políticas de izquierda (Camarero, 2007b). Si bien contamos con algunas obras clásicas sobre la historia económica del período (Díaz Alejandro, 1970; Dorfman, 1970; Facciolo, 1981) así como con otras investigaciones más recientes (Belini y Korol, 2012; Gerchunoff y Llach, 2010; Iñigo Carrera, 2007; Palacio, 2000; Rapoport, 2006; Rocchi, 2005; Schvarzer, 1996), resta aún la pregunta sobre qué incidencia tienen los fenómenos de índole productiva en el plano de la organización laboral y de qué forma esta dimensión modela determinadas vías de organización obrera.

De esta manera, en este artículo se propone, en primer lugar, describir la fisonomía del sector maderero en los años veinte en conexión con las formas que asumió la organización gremial en los lugares de trabajo. En segundo término, examinaremos la evolución del proceso de luchas y enfrentamientos entre patrones y trabajadores para construir una periodización sobre la trayectoria que siguió la estructuración sindical del colectivo obrero. En general, las investigaciones sobre la conflictividad obrera en la década del veinte enfatizan la desorganización sindical y el repliegue posterior a la fallida huelga general de 1921, sin detenerse demasiado en calibrar este fenómeno en los distintos gremios (Bertolo, 1993; Del Campo, 1983; Horowitz, 2015; Rock, 1977). En este punto, nos interesa en particular el rol que jugaron las corrientes de izquierda en tanto sujeto activo dentro de este proceso de sindicalización, que realizó una determinada lectura sobre las condiciones y posibilidades para desarrollar la organización de estos trabajadores (Camarero, 2007a; Ceruso, 2015).

La hipótesis general que guió nuestro trabajo plantea que uno de los elementos determinantes en la disputa entre el sindicalismo revolucionario y el comunismo por la dirección del movimiento obrero argentino fue su variable capacidad de adaptación a las mutaciones dentro del proceso de trabajo y a su iniciativa con respecto al momento político: mientras que el auge sindicalista coincidió con la etapa de maduración de los gremios y los oficios, los comunistas se destacaron donde estos se disolvían y comenzaba a primar la forma industrial moderna. Desde esta perspectiva, el estudio sobre la inserción de los sindicalistas en un gremio altamente calificado como los madereros permitió matizar aquellas visiones que ubicaban a esta corriente sólo en ramas industriales y en los grandes sindicatos del sector transporte y servicios, en contraste con los anarquistas, quienes lo habrían hecho en los gremios de oficio (Falcón, 1987; Suriano, 2001). De modo global, la disputa política entre las corrientes por la dirección de la movilización de trabajadores visibilizó un conjunto de posibilidades de organización que se abrieron u obturaron, según la iniciativa y la lectura que hizo cada tendencia sobre este proceso de estructuración sindical. 
Nuestra investigación tomó como punto de partida el año 1915, cuando comenzaron a aparecer los primeros brotes de reactivación gremial, luego de años de desorganización y repliegue, que eclosionarían en junio del año siguiente en una huelga general maderera. La disponibilidad de un corpus documental de fuentes permitió dotar a esta investigación de un sustento empírico original. Así, un insumo clave provino del periódico gremial editado por el Sindicato de Obreros Ebanistas, Similares y Anexos. De igual manera, fichamos la publicación del Sindicato de Aserradores y Carpinteros de La Boca y Barrancas, La Sierra (1920-1925). Además, analizamos los periódicos de la Federación Obrera Regional Argentina del IX Congreso (FORA IX) y de su sucesora, la Unión Sindical Argentina (USA); prensas partidarias como La Vanguardia (periódico del Partido Socialista - PS), La Internacional (ídem del Partido Comunista - PC); entre otros materiales documentales.

\section{Fisonomía de la industria maderera y el rol del oficio}

A comienzos del siglo XX, el sector de la madera concentró varios miles de trabajadores en una ciudad de Buenos Aires atravesada por transformaciones de envergadura. La crisis económica de 1913 y distintos signos de agotamiento del régimen agroexportador coincidieron con los primeros brotes de un incipiente (aunque sostenido) proceso de industrialización en algunas ramas de la economía, circa 1916 (Belini y Korol, 2012; Llach y Gerchunoff, 2010). En particular, la industria maderera se benefició del fenómeno de industrialización por sustitución de importaciones acaecido durante los años de la Primera Guerra Mundial y, más tarde, con los efectos provocados en la economía nacional por la crisis capitalista internacional de 1929. Por otra parte, las transformaciones sociales en el ámbito metropolitano requirieron al sector maderero nuevos insumos y bienes para la construcción, además de los productos destinados al consumo (Gutman y Hardoy, 2007).

En este contexto, la industria argentina dedicada a la tala y procesamiento de maderas y a la producción de muebles se presentaba como una constelación de pequeñas empresas individuales, con capital y personal muy reducidos y tecnología poco avanzada, comúnmente trabajando a un nivel casi artesanal, donde las normas laborales no estaban escritas y el sistema de control era de carácter familiar. Por sus dimensiones, a los talleres más pequeños se los llamaba "boliches" y constituían la mayoría dentro del sector, como ocurría también con otras ramas de la economía (como el rubro textil). En la ciudad de Buenos Aires, la producción mueblera se expandió con fuerza durante las décadas del veinte y treinta, dispersándose en decenas de talleres y algunas pocas fábricas (Camarero y Ceruso, 2015). En un principio, en los barrios de La Boca, Barracas, Parque Patricios y Pompeya; luego, Balvanera, San Nicolás y Almagro comenzaron a ser la sede de una gran cantidad de establecimientos. Desde los años veinte, en Palermo, Villa Crespo, Paternal y, más tarde, Mataderos.

El hecho de que nuestra investigación haya gravitado fundamentalmente sobre el colectivo de los trabajadores ebanistas amerita explicitar ciertas características peculiares del oficio. La ebanistería se distinguía de la carpintería en que producía muebles más 
elaborados, generando nuevas técnicas; estas complejizaban el universo de oficios afines. De esta manera, existía una división gremial que abarcaba a lustradores, tapiceros, tupistas, maquinistas, doradores, silleteros y escultores. Sin embargo, al analizar la rama de la ebanistería en la ciudad de Buenos Aires hacia 1920, observamos que sólo unos pocos talleres tenían la capacidad de establecer una división del trabajo con funciones desagregadas en oficios parcializados, situándose en un punto intermedio entre la cooperación simple y la manufactura. En la mayoría de los casos, los boliches se caracterizaban por emplear un número mínimo de obreros sin mayor distinción de oficio, trabajando a un nivel artesanal y, por tanto, dependiente de la habilidad del obrero individual. En el plano de la estructuración sindical, los distintos gremios ("anexos") orbitaban alrededor del sindicato ebanista.

A la hora de vincular esta dimensión relativa al proceso de trabajo con las formas de organización sindical, hallamos de utilidad el concepto de "autonomía artesanal" (Montgomery, 1979), conceptualizando el "control obrero de la producción" no como un estado de cosas que existió en algún momento sino como una batalla crónica que asumió una variedad de formas, la primera de las cuales es la autonomía del artesano que aún no ha sido subyugado por la "gran industria" capitalista y que, por ende, habilita un cierto poder de resistencia frente a los deseos de sus empleadores. ${ }^{1}$

Sobre la trayectoria de su organización, los trabajadores de la industria maderera disponían de una gran tradición asociativa y las corrientes del movimiento obrero (socialistas, anarquistas $\mathrm{y}$, sobre todo, sindicalistas) habían tenido una presencia significativa entre ellos desde principios del siglo XX (Marotta, 1960). Por su parte, los comunistas comenzaron a tener una inserción molecular a partir de los años 1922-1923, si bien han aparecido indicios que dan cuenta de un cierto trabajo por parte de su organización antecesora, el Partido Socialista Internacional (PSI), entre los años 1918 y 1920, con la destacada actuación del obrero escultor, Mateo Fossa. En términos generales, se trataba de una fracción de la clase obrera con un importante nivel de politización así como de organización sindical, ambos factores debidos probablemente al alto grado de calificación requerido en la labor y que se expresaba con nitidez en el caso del oficio ebanista. En particular, amerita ser destacado el carácter activo y dinámico de este último gremio, con asambleas casi nunca menores al medio millar de asistentes y una alta tasa de sindicalización, logrando una notable incidencia en el movimiento obrero argentino desde sus orígenes (Camarero y Ceruso, 2015). Podría afirmarse que, por su peso productivo y político, el Sindicato de Ebanistas hegemonizaba la rama. Fue un "bastión” organizativo de los socialistas que pasó a manos sindicalistas, contando además con presencia anarquista y luego comunista.

\footnotetext{
${ }^{1}$ La autonomía artesanal involucraba un "código de ética" que modelaba la conducta de estos trabajadores, los contornos que asumía la organización gremial y las formas de contralor obrero en el ámbito laboral (Montgomery, 1979:14).
} 


\section{6-1921: conquistas reivindicativas y estructuración sindical}

La etapa que comienza en 1916 observó el ascenso ininterrumpido de los reclamos y las luchas de la clase obrera argentina, hasta alcanzar, en 1919, el número de huelguistas más alto de la primera mitad del siglo XX (Iñigo Carrera, 2012). En general, la historiografía sobre movimiento obrero ha señalado, con respecto a la periodización del ciclo huelguístico 1916-1921, la huelga de la Federación Obrera Marítima (FOM), en noviembre de 1916, como su momento de inicio, seguida de un fuerte proceso de luchas, que incluyó extensos y violentos paros en el sector del transporte en 1917 (ferroviarios y marítimos), replicados en dispersas y numerosas huelgas en el ámbito manufacturero (frigoríficos, calzado, metalúrgicos, entre otros) (Bilsky, 2011; Camarero, 2007b; Caruso, 2016; Ceruso, 2015; Horowitz, 2015). Sin embargo, en el caso de la industria de la madera, las luchas obreras ya habían comenzado a tomar forma en 1915, en el marco de un incipiente crecimiento de la conflictividad en la Capital Federal, que despuntaba con una huelga general ganada por los picapedreros en mayo, varias luchas de los choferes y por último, los municipales, en mayo de 1916 (Marotta, 1961). Hacia octubre de 1915, las importantes fábricas de muebles inglesas Sage, Maple y Waring y Gillow entraron en conflicto con sus trabajadores, al igual que en otros talleres más pequeños aunque significativos, Urlich y Bocconi. ${ }^{2}$ Para este momento, el sindicato se encontraba en pleno proceso de reorganización, luego de años de crisis económica, entre 1912 y 1915, con una alta desocupación en el sector ( $\operatorname{circa} 65 \%)^{3}{ }^{3}$

De esta manera, comenzaron a proliferar las luchas reivindicativas, que buscaban recuperar las condiciones de trabajo perdidas en los años anteriores. En junio de 1916, la situación se generalizó al conjunto de los talleres y la dirección sindicalista al frente del gremio de ebanistas declaró la huelga general. ${ }^{4}$ En aquella ocasión, las asambleas no bajaban del millar de trabajadores y la solidaridad de clase atravesaba las distintas etnias y nacionalidades: en la rama existían más de un centenar de talleres de patrones "rusos"5, donde trabajaba un enorme porcentaje de obreros judíos en condiciones inferiores al resto del sector y por salarios exiguos. El resultado favorable para los obreros, varios meses después, determinó una nueva relación de fuerzas hacia el interior de los talleres. ${ }^{6}$

Entre 1917 y 1920, se sucedieron una multiplicidad de conflictos laborales in crescendo hasta llegar al súmmum de las huelgas, en 1919, unos meses después de la masacre de la Semana Trágica. ${ }^{7}$ Durante esta etapa, los trabajadores consolidaron su

\footnotetext{
2 "Informe de secretaría”, El Obrero En Madera, núm. 72, noviembre 1915.

3 "Historia del Sindicato de Ebanistas", El Obrero Ebanista, núm. 94, julio 1920.

4 "Declaración de la huelga - La asamblea de la Casa Suiza", La Vanguardia, 13/6/1916.

5 En la época, a los inmigrantes (en particular judíos) de Europa oriental se los llamaba genéricamente "rusos". Véase Visacovsky, 2016.

6 “Obreros ebanistas - Estado de la huelga", La Vanguardia, 15/8/1916.

7 "Movimiento sindical”, El Obrero Ebanista, núm. 77, abril 1917; "Huelga de obreros lustradores", La Vanguardia, 8/6/1917; "Movimiento sindical. Triunfos obreros”, El Obrero Ebanista, núm. 80, enero 1918; "Triunfo obrero en la casa Michelotti", La Vanguardia, 18/6/1918; "Movimiento sindical", El Obrero Ebanista, núm. 90, noviembre 1919.
} 
organismo sindical, votando delegados en los establecimientos (uno cada diez trabajadores) y adoptando la "tarjeta sindical", sin la cual ningún obrero podía ingresar a los lugares organizados. ${ }^{8}$ Llegado a un extremo, el sindicato conseguía que el capitalista cediera a sus reclamos ya que, de lo contrario, fuera más o menos grande su poderío, no contaba con la fuerza de trabajo necesaria. Más aún, algunas crónicas destacaban que los rompehuelgas terminaban arruinando los trabajos y las herramientas de los talleres. ${ }^{9}$

De este modo, el trabajo calificado o autonomía artesanal resultaba el principal camino sobre el cual transcurría la organización, dentro un sector productivo escasamente desarrollado en términos capitalistas. Apoyándose en una relación de fuerzas favorable a los trabajadores, la organización estable en los sitios laborales permitió garantizar la jornada de 44 horas semanales, el seguro por accidentes de trabajo desde el momento en que este se produjera, la abolición del trabajo a destajo, la provisión de herramientas grandes y el pago de viáticos en caso de trabajos externos, entre las reivindicaciones más destacadas. ${ }^{10}$

Por otra parte, el contralor obrero sobre la contratación derivó en una alta tasa de sindicalización. Según las fuentes consultadas, las cotizaciones anuales al Sindicato de Ebanistas pasaron del mínimo histórico de 2.000 en 1915, a 4.000 en 1916, 7.000 en 1917, 17.000 en $1918 \mathrm{y}$, finalmente, 33.800, en 1919. ${ }^{11}$ Asimismo, en la medida en que se incrementaban las suspensiones con la mengua del trabajo, desde el sindicato ebanista se proponía el establecimiento del turno. En síntesis, planteamos que existió una vinculación directa entre la "autonomía artesanal" derivada de la configuración del proceso de trabajo y la extensión o atrofia de la organización sindical.

Para comprender el mapa político de la etapa, debe anotarse la trayectoria de la estrategia sindicalista, tendiente a la consecución de reivindicaciones parciales mediante el método de la estructuración sindical de los personales y la votación de delegados en los lugares de trabajo como paso previo para afrontar las luchas, dirigidas a conseguir mejores condiciones de explotación de la fuerza de trabajo, ya sea en el plano de la explotación material de la misma, es decir, como fuente de valorización del capital; ya sea en el plano del mercado, esto es, en tanto valor de cambio o valor, equivalente a una determinada cantidad de dinero (el salario del obrero). En otras palabras, el ciclo de lucha y agitación huelguística que continuó de 1917 a 1920 consolidó esta tendencia por establecer condiciones "especiales" de explotación de la fuerza de trabajo en la industria maderera. Con esta orientación, el sindicalismo revolucionario afianzó su hegemonía dentro del gremio, si bien no debe menospreciarse el lugar que ocupó el Partido Socialista (PS) ni otras corrientes menores, como el Partido Socialista Internacional (PSI). Aunque difícil de medir, el ascendiente del PS entre estos trabajadores fue relevante (véase el espacio dedicado al gremio en La Vanguardia), pese a que su implantación no fue mucho más allá

\footnotetext{
8 “La tarjeta sindical”, El Obrero Ebanista, núm. 81, marzo 1918.

9 "En la casa Waring y Gillow”, La Vanguardia, 20/10/1915.

10 "Nuestras grandes conquistas. Las 44 horas son un hecho", El Obrero Ebanista, núm. 87, abril 1919.

${ }^{11} \mathrm{Si}$ bien los números no son exactos, brindan una pauta aproximada de cuál fue la evolución que siguió la estructuración sindical. "Historia del Sindicato de Ebanistas”, El Obrero Ebanista, núm. 94, julio 1920.
} 
de algunas figuras individuales (como la de Israel Landan entre los obreros judíos o Luis Fernández entre los escultores), opacada por la intensa actividad sindicalista. Resalta, en cambio, la escisión entre acción gremial y acción política y, por lo tanto, el hecho de que el socialismo haya resultado mucho más relevante como empresa política, social, cultural y en parte intelectual, pero intrascendente como expresión orgánica de la clase obrera (Camarero y Herrera, 2005). En general, tanto los sindicalistas como los socialistas impulsaron la huelga parcial como forma de lucha, sin una intención por extenderla más allá de los conflictos puntuales en cada uno de los lugares de trabajo.

Por otra parte, el mapa de las corrientes estaría incompleto si desconociéramos el rol del anarquismo, que militaba desde las estratégicas posiciones ocupadas por los gremios aserradores, capaces de paralizar el procesamiento de la materia prima esencial para la industria del mueble (si bien la rama también se proveía de insumos extranjeros). Aquí, las pésimas condiciones laborales y el rezago salarial acabaron por prender la chispa y los gremios de dirección ácrata (con presencia de los socialistas) no dudaron en declarar la huelga general por tiempo indeterminado. Valga de ejemplo: sólo en 1919, ocurrieron dos paros totales entre los obreros aserradores (Boca y Barracas y Tigre y San Fernando, respectivamente), dos en el pequeño gremio de torneros y uno entre los carpinteros de flota y de ribera, en solidaridad con un paro de los trabajadores de construcciones navales. ${ }^{12}$

Por último, cabe anotar que la otra premisa de la acción sindicalista, además de la alta calificación de la mano de obra, era el nivel de ocupación dentro de la industria, que tendía a ser mayor entre los meses de mayo a octubre. Los límites de esta experiencia se verificaron, en todo caso, en ocasión del germinal pasaje de la manufactura a la gran industria, en la medida en que se tecnificó una parte de la rama, durante la segunda mitad de la década de 1920. ${ }^{13}$ Como veremos en un momento, estos cambios repercutirían en las formas de organización laboral y quien mejor asimiló estas transformaciones fue el puñado de militantes del naciente PSI, luego Partido Comunista (PC). A través de modulaciones claves en su repertorio organizacional, el PC logró implantarse en las mayores concentraciones obreras y fábricas, generando una moderna estructuración sindical por ramas industriales, en desmedro de los oficios y gremios (Camarero, 2007a).

\section{1-1924: desorganización sindical y fragmentación política}

Los años que siguieron a la derrota del ciclo huelguístico cerrado en 1921 coincidieron con un cambio de gobierno y, en términos generales, marcaron el origen de la industrialización argentina y su modernización capitalista (Schvarzer, 1996; Villanueva, 1972). El revés ocasionado por la fallida huelga general, en junio de 1921, marcó un punto de inflexión en lo que podría considerarse el "período de oro" de la FORA IX, dirigida mayoritariamente por los sindicalistas, si bien no era menor el peso de los socialistas y de otros gremios libertarios y "autónomos". No obstante lo cual, en paralelo a la llegada de importantes inversiones del capital extranjero, prosiguió el proceso de estructuración

\footnotetext{
${ }^{12}$ Véanse los “informes gremiales” en El Obrero Ebanista y La Vanguardia, correspondientes al año 1919.

13 “La industria de la madera. Su situación y perspectivas", Acción Obrera, núm. 47, diciembre 1928.
} 
sindical en las nuevas ramas de la economía, multiplicándose los intentos de organización en los lugares de trabajo (Camarero, 2007b; Ceruso, 2015).

Dentro de las fábricas y talleres de la industria del mueble, los patrones pretendieron avanzar sobre el contralor sindical en los lugares de trabajo, apoyándose en la fuerza paraestatal de la Asociación Nacional del Trabajo (ANT) y la Liga Patriótica Argentina (LPA), logrando en muchos casos hacer retroceder con relativo éxito las conquistas obreras del lapso previo. En el mapa político de las corrientes, el período bajo estudio estuvo atravesado por divisiones en el movimiento obrero, con la aparición de nuevas centrales sindicales y la emergencia de rupturas que dieron lugar a novedosas organizaciones. Sin embargo, los factores enunciados no implicaron, como muchas veces se ha querido marcar, la inexistencia de luchas ni la desaparición de los organismos gremiales (Rock, 1977; Romero, 1995).

En el sector bajo estudio, las crónicas sindicales comenzaron a reflejar este retroceso en los sitios laborales, señalando que había resultado más difícil sostener las conquistas que conseguirlas y afirmando que “...como corolario de la última reacción capitalista-estatal, algunos patrones han pretendido (...) desconocer las condiciones establecidas por la organización...”. ${ }^{4}$ De forma general, los años que van de 1921 a 1923 fueron años de poca actividad y de crisis dentro de la industria, con una extensión de los desempleados y la consiguiente desorganización de los trabajadores.

El repliegue en el plano de la estructuración sindical también hizo eco en el activismo. Desde las páginas del periódico ebanista, se caracterizaba que "el movimiento obrero atraviesa un período de transición" coincidente con el "actual estado de depresión de la organización obrera". ${ }^{15}$ Del mismo modo, se reprendía a los delegados de los talleres de la siguiente forma: "No tiene justificativo alguno la desidia observada en este último tiempo en una buena parte de los delegados", informando que nadie asistía a las reuniones periódicas ni tampoco se interesaba por la organización. ${ }^{16}$ En el ámbito de los obreros aserradores, la tónica parecía similar: "Estamos viviendo momentos aciagos para la clase trabajadora (...) dado la apatía que domina a una gran mayoría de los trabajadores que se apartan del seno de la organización...". 17 Un año más tarde, el diagnóstico permanecía invariable: "El estado de apatía y retraimiento que se nota actualmente en la organización obrera es el tema obligado de todos los comentarios." ${ }^{18}$; otros destacaban que “...actualmente se atraviesa por una época de estancamiento y de inercia colectiva..." año siguiente, el metalúrgico comunista, Pedro Milesi, aún arengaba desde las columnas: "Existe en la actualidad un buen número de militantes en la idéntica situación de los lagartos en invierno.". 20

\footnotetext{
14 “Actividad sindical”, El Obrero Ebanista, núm. 107 agosto 1921.

15 "Informe de Secretaria", El Obrero Ebanista, núm. 110, diciembre 1921.

16 "A los delegados", ibídem.

17 "La hora actual”, La Sierra, núm. 10, septiembre 1921.

18 “La organización y los dogmas”, El Obrero Ebanista, núm. 114, diciembre 1922.

19 "De nuestra incumbencia. Situación del gremio", La Sierra, núm. 13, octubre 1922

20 "Lo que debe hacerse para luchar con éxito", El Obrero Ebanista, núm.119, noviembre 1923.
} 
La desorganización en los lugares de trabajo conllevó una vuelta hacia atrás por sobre los derechos y obligaciones contraídos con los patrones, arrancados en el período de alza huelguística 1917-1920. El retroceso fue posible, en buena medida, a partir del desconocimiento o despido del delegado por parte de los dueños de los talleres, concentrándose la mayoría en el año $1922 .^{21}$ Cabe señalar que la figura del representante sindical en el lugar de trabajo era clave para sostener las condiciones laborales fijadas por el gremio, en el contexto de una amplia dispersión geográfica de establecimientos pequeños y con una reducida concentración de personal (entre cinco y veinte), salvo algunas pocas grandes fábricas. A la inversa, la desvinculación del delegado permitió vulnerar la jornada de $44 \mathrm{hs}$ y restablecer el sistema de trabajo a destajo, dos elementos claves para maximizar la tasa de ganancia empresarial en la industria.

Así, los conflictos motivados por el ingreso de personal por fuera del sindicato fueron frecuentes. En la importante mueblería Thompson, la gerencia logró volver a poner en pie los "centuriones de trabajo", una suerte de cuerpo especial de obreros rompehuelgas (Ceruso, 2015). En talleres como el de Rizza o el de Giudice (que venía de una huelga de cinco meses) los crumiros fueron provistos por la LPA. ${ }^{22}$ Cabe destacar que, aunque la presencia de rompehuelgas ofrecidos por esta última asociación y la ANT fue permanente (sobre todo en las casas más importantes), las características artesanales que rodeaban el proceso de trabajo seguían constituyendo una barrera infranqueable para obreros sin ningún conocimiento del oficio.

Como fue señalado, el período comprendido entre 1921-1923 estuvo signado por el repliegue de la estructuración sindical y de la conflictividad obrera. Sin embargo, esto no impidió que, pese a las divisiones imperantes y guerras intestinas, en diciembre de 1923, luego de más de un año de preparación y debates, se conformara el Sindicato Obrero de la Industria del Mueble (SOIM), impulsado fundamentalmente por el Sindicato de Ebanistas. ${ }^{23}$ El SOIM agrupaba varios de los oficios lindantes en la industria, en aquel momento separados en distintas asociaciones: el errático Sindicato de Escultores en Madera; el Sindicato de Torneros en Madera (refundado en 1918); la Unión de Tapiceros; el Sindicato de Doradores en Madera. En el contexto del repliegue generalizado del movimiento obrero, en realidad se trataba de un reagrupamiento sobre la base de la necesidad más que de la virtud; vale señalar que la fundación del SOIM no pudo solucionar las disputas crónicas entre carpinteros y ebanistas, que continuaron transitando vías sindicales diferentes.

En el plano político se abrió un período de crisis y reconfiguración del mapa de las fuerzas que intervenían en el seno del movimiento sindical argentino. Si en el terreno de la FORA IX se observaba un retroceso del espacio sindicalista, el declive político fue notorio entre los trabajadores ebanistas, uno de los puntos claves de gravitación de esta tendencia en el movimiento obrero. En este sentido, la "autonomía artesanal" había permitido desenvolver una estrategia cimentada en los postulados sindicalistas respecto a la

\footnotetext{
21 “Informe de Secretaría", El Obrero Ebanista, núm. 112, mayo 1922.

22 "Informe de Secretaría", El Obrero Ebanista, núm. 110, diciembre 1921.

23 “Constitución del Sindicato de la Industria del Mueble”, El Obrero Ebanista, núm. 119, noviembre 1923.
} 
capacitación de la clase obrera sobre el dominio de la producción (Bilsky, 2011) y de una fuerte centralización organizativa desde la Comisión Administrativa (CA) del Sindicato de Ebanistas, mediante un sistema de representación delegativa en los talleres. ${ }^{24}$ De allí que la desestructuración sindical posterior implicó una ruptura de los vasos comunicantes entre la dirección de la CA sindicalista y los lugares de trabajo, a lo cual contribuyó la falta de control sobre las condiciones laborales (jornada, salarios, contratación, entre otros).

En este punto, el retroceso del sindicalismo revolucionario habilitó un espacio para que empezaran a cobrar mayor visibilidad otras corrientes políticas que, hasta el momento, habían permanecido relativamente al margen del proceso de lucha y organización obrera, monopolizado por los sindicalistas y los socialistas. De alguna manera, los límites alcanzados hacia 1920 por las tres principales culturas políticas del movimiento obrero (socialismo, sindicalismo y anarquismo) se vehiculizaron a través de una serie de debates de carácter programático-estratégico, tanto hacia el interior como entre las organizaciones. En líneas generales, la Revolución rusa, en noviembre de 1917, implicó la crítica de los supuestos que aglutinaban estas formaciones políticas y abrió un juego de realineamientos que, en muchos casos, dio lugar a nuevas estructuras organizativas. ${ }^{25}$ Así, el debate sobre si apoyar o no el proceso soviético, en primer lugar y respecto a si adherir o no a una organización internacional de trabajadores, en segundo término, delimitó los campos más allá de las identificaciones "políticos" y "anti-políticos", dado un fenómeno revolucionario ajeno a los cánones reconocidos.

A fines de 1920, se puede reconocer la emergencia de tres corrientes de opinión que, en mayor o menor medida, empezaron a intervenir de forma sistemática entre los trabajadores, a expensas de los espacios políticos predominantes con anterioridad: en primer lugar, en el campo del Partido Socialista (PS), una escisión por izquierda dio origen al Partido Socialista Internacional (PSI), luego Partido Comunista (PC), aunque cabe señalar que es factible rastrear los orígenes de estas disidencias en todo el período previo de intervención del "Comité de Propaganda Gremial"26; en segundo término, dentro de la corriente del sindicalismo revolucionario, apareció un núcleo de sindicalistas "rojos", simpatizantes de la revolución de octubre, agrupados en el periódico La Batalla Sindicalista (1920-1923) (Aquino, 2015); en tercer lugar, el sector de anarquistas que apoyaban la experiencia soviética, nucleado en torno a los periódicos Bandera Roja, primero, y El Trabajo, después (Doeszwijk, 2013).

Quizás por la fugacidad que presentaron, la existencia de estos últimos dos grupos y su incidencia en el movimiento obrero de la época han sido poco estudiadas y, en la mayoría de las ocasiones, directamente se los ha confundido (o invisibilizado) dentro del espectro sindicalista, anarquista o comunista. No obstante, creemos que desempeñaron un papel destacado en la reconfiguración del mapa político-sindical circa 1920. Cada uno de

24 Desde la visión sindicalista, el dominio del taller acrecentaba la "moral revolucionaria" de la clase productora, cuya capacitación progresiva sobre el proceso de trabajo tendía hacia la dirección total de la sociedad capitalista. "La revolución obrera", El Obrero Ebanista, núm. 94, julio 1920.

${ }^{25}$ Para una descripción general de este proceso desde el punto de vista de la historia de las ideas políticas, véase Pittaluga, 2015.

${ }^{26}$ Sobre la experiencia del Comité de Propaganda Gremial del PS (1914-1917), véase Camarero, 2015. 
estos agrupamientos, además, tuvo sus propias divisiones, entre aquellos más proclives a aceptar la dirección bolchevique del proceso revolucionario y quienes la rechazaban.

En el terreno de la movilización obrera, luego del repliegue post-1921, el análisis de los conflictos laborales en 1923 arrojó un puñado de luchas de carácter defensivo, que intentaron ponerle un límite a la ofensiva patronal en un escenario de baja conflictividad; algunas de ellas fueron de larga duración, como en la importante casa Maple por más de ocho meses, o en Rosario, donde una huelga general del gremio duró más de seis. ${ }^{27}$ Hacia 1924 se constata un incremento de la actividad huelguística, con más de una docena de paros de actividades, casi la mitad en "boliches" judíos (pequeños talleres) aunque también en grandes casas como Lapidus y Smud y en la inglesa Maple, y contra la rebaja salarial en ocasión de la ley de jubilaciones, en las fábricas de muebles finos, Thompson y Nordiska. ${ }^{28}$ A continuación, se reseñará la etapa abierta con el alza relativa de la movilización obrera, señalando cuáles fueron sus expresiones en el plano de las corrientes políticas y en particular en la estructura organizativa del PC.

\section{4-1925: el viraje estratégico del PC y la formación del Grupo Rojo de la Industria del Mueble}

En el marco de un ligero repunte de la conflictividad obrera durante 1924, para 1925 se calculó una cifra de conflictos en los lugares de trabajo similar al año previo ${ }^{29}$; además, entre los aserraderos se desarrolló un intenso paro en el taller "El Eje", que duró más de 43 días e involucró unos 65 obreros, concitando la solidaridad de los otros talleres de la zona de La Boca y Barracas. ${ }^{30}$ Sobre el fondo de estas luchas reivindicativas, a mediados de 1920, el PC de Argentina, siguiendo los lineamientos de la III Internacional vertidos en su V Congreso, reformuló las formas de imbricación y penetración en el movimiento obrero, siendo uno de los pioneros del continente en poner en práctica la "bolchevización" y la "proletarización" (Camarero, 2007a; Ceruso, 2015). La primera implicaba que el partido estaría incluso más subordinado a las indicaciones de Moscú y que adoptaría plenamente un "centralismo democrático" de carácter singular, reinterpretado por la dirección argentina de aquel momento (alineada con las posiciones oficiales) como una pérdida de autonomía de las instancias partidarias inferiores. Además, se aplicaron modificaciones en la estructura interna, fomentando la multiplicación de las células y un mayor compromiso militante. De allí se resolvía que "...cada afiliado debe trabajar 'individualmente' a los obreros para atraerlos al partido (...) deben buscar que todos los afiliados a la célula sean activos y participen en un trabajo determinado, de esos pequeños trabajos que, sistemáticamente

\footnotetext{
27 “La huelga de la casa Maple y Cía.”, El Obrero Ebanista, núm. 116, julio 1923; "Informe de Secretaría”, El Obrero Ebanista, núm. 117, septiembre 1923; "Huelgas”, El Obrero Ebanista, núm. 119, noviembre 1923.

${ }^{28}$ Los dueños de boliches mencionados eran: Aaron Apartin; Tabacman; Gregorio Brodesky; Epelman hnos.; Leon Waisman; Abraham Rosenfeld. "Sindicato Obrero de la Industria del Mueble", La Vanguardia, 29/7/1924; "Talleres en huelga”, Acción Obrera, núm. 4, agosto 1924.

29 "Huelgas en la Capital Federal durante 1925. Datos del primer semestre", La Vanguardia, 24/10/1925.

30 “La huelga en los talleres 'El Eje'”, La Vanguardia, 6/1/1925.
} 
llevados a cabo, son los que crean las grandes agitaciones, el verdadero contacto con las masas...". ${ }^{31}$ El involucramiento era total y planteaba que cada comunista individualmente debía "trabajar la fábrica donde están ocupados", en pos de conformar una célula que pudiera abarcar tanto los problemas internos como del radio barrial.

Por su parte, la "proletarización" complementaba este reordenamiento interno y se orientaba a apuntalar un mayor perfil obrero para el partido, mediante la proliferación de la estructura de células sobre las cuales se debía basar la reorganización. La célula, sita sobre todo en el ámbito fabril (aunque también las había "de bloqueo" y "de calle"), era una estructura exclusivamente partidaria, formada por entre tres y veinte militantes, en general con un funcionamiento clandestino (Camarero, 2007a; Ceruso, 2015). De este modo, los comunistas cimentaron una metódica y tenaz disposición militante que, aunque gradual, a posteriori resultó "exitosa". En el creciente medio industrial, el PC reflejó las modificaciones en su estructuración mediante un avance significativo en la organización obrera, habida cuenta de la débil presencia de otras corrientes políticas y de las pésimas condiciones de trabajo. Como bien señalan Camarero y Ceruso (2015), ambos elementos, entre otros, coadyuvaron para conformar un terreno fértil para la experiencia celular.

Entre los obreros de la madera, impulsaron primero la "Agrupación Comunista de la Madera" (abarcando a aserraderos y carpinteros) que coexistió con la "Agrupación Comunista de Obreros Ebanistas" y luego con el poderoso "Grupo Rojo de la Industria del Mueble", que referiremos en breve. Inicialmente, se destacaron en el gremio los militantes del PC: Mateo Fossa y Serafín Garbini (ambos escultores que venían desde el socialismo y la ruptura del PSI), Salomón Elguer (referente clave dentro de la juventud comunista, "La Fede") y Guillermo Bossio (desde 1922 al menos). En un principio, desarrollaron estructuras celulares dentro del prestigioso establecimiento Ponti, en la fábrica de sillas Colombo y en la casa de origen judío Lapidus. Posteriormente, los comunistas lograron implantarse en las más importantes Thompson, Sage y Nordiska (es decir, las mueblerías extranjeras, donde la concentración obrera era, por lejos, la más alta del sector). También penetraron en los talleres medios, sobre todo entre los judíos, si bien en este rubro la presencia sindicalista dificultó el proceder (Camarero, 2007; Kersffeld, 2012). En algunos casos, la creación de célula fue acompañada por la publicación de un periódico de empresa, "...escritos con la sencillez característica de los trabajadores, sin mucha técnica ni filosofía, sin mayor cuidado de la redacción, pero eso sí, llenos de sinceridad y de dedicación al trabajo...". 32 El primer número de la célula de la casa Sage, Frente Único, apareció en junio de 1926; en Lapidus y Smud, el periódico de fábrica se denominó La Garlopa, por la herramienta de los ebanistas. ${ }^{33}$

Gracias a las modificaciones en su repertorio organizacional, los comunistas lograron hacerse con el control de la dirección sindical del SOIM y de la redacción del periódico desde mediados de 1924, durante casi un año aproximadamente, lo cual abrió una suerte de "interregno soviético" en un gremio históricamente hegemonizado por los

\footnotetext{
31 "Informe del compañero Penelón sobre la bolchevización de nuestro partido", La Internacional, 22/7/1925.

32 "Los nuevos paladines del comunismo", La Internacional, 3/6/1926.

33 "Progresos de la prensa proletaria", La Internacional, 26/6/1926.
} 
sindicalistas. ${ }^{34}$ Desde esta posición, los esfuerzos del PC fueron en el sentido de centralizar lo más posible la acción sindical. En términos estratégicos, levantaban la propuesta del "frente único" de clase entendido, según Mateo Fossa, como "...un acuerdo mínimo para concentrar las fuerzas divididas. El frente único dura tanto como la causa que lo hizo nacer" y empalmaba con la exigencia de formar un sindicato por industria que centralizara todos los oficios y labores involucrados en las distintas fases del proceso de trabajo. ${ }^{35}$ No obstante, desde el sindicalismo, Pedro Daverio contestaba que el frente único sólo era posible "...con obreros, no con partidos políticos". 36

Por otra parte, al igual que en otras ramas de la economía y en particular en los nuevos ámbitos fabriles, el PC se dio la tarea de organizar a los sectores más explotados de la industria, en este caso los jóvenes aprendices y los inmigrantes, fundamentalmente de raigambre judía. En el campo de los aprendices, se trataba de un grupo compuesto mayoritariamente por menores de edad y, en general, "invisibilizado" por sus contemporáneos puesto que el Sindicato de Ebanistas bajo el mando de los sindicalistas les había denegado sistemáticamente su sindicalización, concentrándose la afiliación en el segmento de oficiales (la mayoría del gremio). ${ }^{37}$

En este nuevo cuadro, los sindicalistas "rojos" (adherentes a la Revolución rusa) se volvieron cada vez menos visibles en un espacio acaparado por el PC; a fines de 1924, publicaban esporádicamente el periódico Sindicato Rojo. Órgano de la Agrupación Sindicalista. $^{38}$ En junio de 1925, su figura más visible, Aurelio Hernández, ingresó "oficialmente" al partido junto con otros militantes de las filas sindicalistas (Luis V. Sommi, Eduardo Carugatti, Manuel Torreiro, Emilio Ginochio y Camilo López) y anarquistas (el experimentado escultor Antonio Romeo y Pedro Jungalás). ${ }^{39}$ Con todos ellos, los comunistas formaron un poderoso Grupo Rojo de la Industria del Mueble, de oposición a la CA del sindicato (Camarero, 2007a). No obstante el empuje inicial del Grupo Rojo, este se resintió al poco tiempo, cuando sufrió la pérdida de Mateo Fossa así como de otros militantes que fueron expulsados del partido, después del VII Congreso (diciembre de 1925), conociéndose como los "chispistas", debido al periódico La Chispa que editaron entre 1926 y 1929.

De modo general, podemos afirmar que las distintas iniciativas y propuestas de reorganización sindical de los comunistas no pasaron de ser meras intenciones puesto que, hacia mediados de 1925, los sindicalistas recuperaron el rumbo general del sindicato de muebleros y de su periódico, desplazando a los "rojos". En esta forma abrupta finalizó la corta experiencia de los comunistas al frente del SOIM. ${ }^{40}$ Los sindicalistas proclives a la

\footnotetext{
${ }^{34}$ Durante este período, desde noviembre de 1924 hasta febrero de 1925 inclusive, el periódico se denominó El Obrero del Mueble, volviendo a su nombre original, Acción Obrera, en marzo de 1925.

35 "Frente único", Acción Obrera, núm. 6, octubre 1924.

36 "Frente único", Acción Obrera, núm. 6, octubre 1924.

37 "Problemas de interés", Acción Obrera, núm. 6, octubre 1924.

${ }^{38}$ Referido en "Polémica. El sindicato y la ISR", El Obrero del Mueble, núm. 8, diciembre 1924.

39 "Hacia Moscú: Un grupo de anarquistas y sindicalistas se adhiere a la tercera internacional. Incorporación de varios revolucionarios al Partido Comunista", La Internacional, 16/6/1925.

40 “Comisión de prensa”, Acción Obrera, núm. 11, marzo 1925.
} 
"prescindencia política" o de la "guardia vieja" (como los habían llamado los comunistas), retomaron plenamente el control del sindicato del mueble, estableciendo una suerte de pacto con un sector de militantes anarquistas, encabezado por Alfonso Silveira y con los sindicalistas "rojos", que hasta hace poco habían formado parte de la conducción del gremio con el PC. El viernes 22 de enero de 1926, sindicalistas "autonomistas" y "rojos" sellaron una suerte de pacto de "unidad", concertando la postulación de Emilio Mársico (rojo) como el nuevo secretario general del SOIM. ${ }^{41}$ Teniendo en cuenta este nuevo marco de alianzas, los sindicalistas afianzaron una sólida posición dentro de la USA, favorecidos también por el peso relativo que tenía el gremio del mueble en un marco general de declive de la actividad sindical de los otros sectores, en particular en términos de afiliados ya que, si bien el sindicato del mueble había decrecido en cotizantes (oscilando en 1926 entre 1.790 y 2.800), era el "sindicato numéricamente más importante" frente a la exigua organización que presentaba el movimiento obrero en aquel momento. ${ }^{42}$

Para concluir este apartado, cabe señalar que lo significativo del PC (y que, en última instancia, representaba una superioridad relativa frente al resto de las corrientes) era una comprensión más global sobre las tendencias que operaban por detrás de la crisis económica y de la desocupación así como del proceso de industrialización y de maquinización creciente, realizando una íntima vinculación con la táctica y la estrategia que debía adoptar el organismo sindical para alcanzar los desafíos que planteaba la nueva etapa. En el próximo apartado nos dedicaremos a examinar estas transformaciones.

\section{6-1928: modernización capitalista, desocupación y conflictividad laboral}

La modernización capitalista en la industria del mueble empezó a ser percibida con mayor claridad por los contemporáneos a partir de 1926. La mecanización del proceso productivo y una paulatina racionalización de la fuerza de trabajo se destacaban en especial entre las fábricas de capitales extranjeros (Thompson, Nordiska, Sage), si bien el fenómeno alcanzaba al resto de la industria, afectándola de distintas formas. Una primera aproximación a la fisonomía de los establecimientos de aquel momento, por lo tanto, separaba, de un lado, a los grandes ámbitos fabriles, que empleaban varias decenas de obreros, contando con secciones que albergaban las nuevas máquinas: pulidoras, lustradoras y barnizadoras; enchapadoras mecánicas; moldureras que hacían tres molduras simultáneas; máquinas malletadoras y escopladoras a cadena, entre otras. ${ }^{43}$ Del otro costado, el universo multiforme y heterogéneo de cientos de pequeños y medianos talleres, que funcionaban con personales de entre cinco y veinte trabajadores; en su interior, podía hallarse alguna máquina para cantear y regruesar junto con unas sierras de cinta o de disco. En no pocas ocasiones, estos "boliches" trabajaban como una empresa "subsidiaria" de la producción de otra mayor. De alguna manera, puede entenderse este último aspecto como parte de una tendencia más profunda hacia la concentración y la centralización del capital

\footnotetext{
41 "A los obreros del mueble", La Internacional, 20/1/1926.

42 "El miedo a los sindicatos grandes", Acción Obrera, núm. 23, mayo 1926.

43 "La industria de la madera. Su situación y perspectivas", Acción Obrera, núm. 47, diciembre 1928.
} 
dentro de esta industria, determinando una configuración geográfica específica en los barrios de de Villa Crespo, Paternal, Caballito, Palermo, con una amplia dispersión de los talleres.

En segundo término, colindante con la introducción progresiva de maquinaria dentro del proceso productivo, se verificaba un decrecimiento de la calidad de los muebles terminados y un incremento de la productividad del obrero en términos individuales. Esta no sólo estaba determinada en función de una máquina que abreviaba los "tiempos muertos" (con la puesta en práctica de reglamentos, como en la casa Thompson ${ }^{44}$ ) sino también gracias a la aplicación de nuevas modalidades en la fabricación de muebles, como la madera terciada (“...está a la orden del día en todas las fábricas, por economizar tiempo y mano de obra...") y el enchapado, utilizado en general por los boliches (en una amplia proporción, judíos), que permitía imitar los estilos "chippendale" y "francés", reduciendo drásticamente el costo del producto final. ${ }^{45}$ Así, el ensamble de muebles a partir de partes pre-fabricadas se masificó, apareciendo los llamados "trabajos de batalla", en los cuales “...cada una de las partes se coloca tal cual sale de la máquina, sin pulir absolutamente nada, cubriéndosele luego con un mazacote a modo de lustre a fin de darle la apariencia engañosa para los compradores...". 46 Por último, algunas fuentes señalaban la importación de muebles del extranjero como otro factor que agravaba la crisis.

La contracara del fenómeno de modernización capitalista era una desocupación crónica en las distintas ramas de la industria, acicateada por la concurrencia ininterrumpida de mano de obra calificada que provenía de Europa y se ocupaba por fuera de las reglamentaciones sindicales, hundiendo las condiciones laborales (Avni, 1983; Jmelnizky y Erdei, 2005). ${ }^{47} \mathrm{El}$ desempleo en la industria del mueble fue notorio a mediados de 1926 , cuando se resaltaba que "A pesar de encontrarnos en el período de invierno, que por lo general es el período de abundancia de trabajo, se encuentran desocupados una buena cantidad de compañeros...". ${ }^{48}$ En los años subsiguientes, se evidenció que, lejos de tratarse de un fenómeno pasajero, aparecía como un elemento estructural de la situación de la industria. $^{49}$

Una de las consecuencias inmediatas de la sobreoferta de fuerza de trabajo era el aumento de la competencia entre los trabajadores. En esta dirección, los intentos empresariales por racionalizar y lograr una mayor eficiencia productiva fueron permanentes. En las grandes fábricas como Nordiska -que en ese entonces ocupaba

\footnotetext{
44 "Casa Thompson", La Internacional, 21/5/1925.

45 "Las causas de la crisis", Acción Obrera, núm. 34, agosto 1927.

46 "Reseña de las actividades sindicales durante el primer semestre de 1928", Acción Obrera, núm. 42, junio 1928.

${ }^{47}$ Según varias fuentes de época, calculamos que entre 1.500 y 2.000 judíos se empleaban en la industria del mueble, estando organizados menos de la mitad.

48 "Informe de Secretaría", Acción Obrera, núm. 24, junio 1926.

49 “...la desocupación, aunque con algunas alternativas de aumento o disminución en el porcentaje numérico de desocupados, se presenta en la actualidad como una cuestión de carácter permanente. (...) En el mes de julio, que se considera el de más intensidad en el trabajo, existe un porcentaje de desocupados bastante considerable, hecho nada común en años anteriores.". "Reseña de las actividades sindicales durante el primer semestre de 1928”, Acción Obrera, núm. 42, junio 1928.
} 
alrededor de 190 obreros- se buscaba reducir los costos empleando obreros menos preparados para tareas de mayor calificación como, por ejemplo, poniendo peones a trabajar con máquinas a la par de medio-oficiales y oficiales. ${ }^{50}$

En estas circunstancias, la desocupación impactó directamente en la desarticulación del organismo sindical. Según un artículo aparecido en septiembre de 1925, había que reorganizar "la mitad del gremio". ${ }^{1}$ En 1928, otra nota, escrita por Hernández, aseguraba que el $65 \%$ de los obreros de la industria del mueble estaban desorganizados mientras que en los "años de lucha" (1917-1920) la tasa de sindicalización había alcanzado a un 80\% aproximadamente; según Fossa, estas cifras eran "completamente exactas". 52 Por lo tanto, a partir de la desarticulación de los resortes gremiales, los patrones reinstauraron paulatinamente el trabajo a destajo, la jornada de 48 horas o más, el pago quincenal y la negativa a proveer herramientas; una editorial sindicalista asumía que "...no nos extrañaría el retorno a la época, que parecía tan lejana, en que el obrero ebanista debía también suministrarse el banco.". 53 A su vez, se reinstaló el trabajo a domicilio (muchas veces, llevándoselo después de terminar la jornada laboral) y se multiplicaron los obreros que hacían "changas". 54

No obstante la mengua en las cotizaciones y con asambleas muchas veces menores a los 100 concurrentes, estos años no estuvieron exentos de conflictos. Por caso, en un año sintomático por el reflujo de la movilización obrera y con una actividad sindical reducida a su mínima expresión como fue 1926, en la industria bajo estudio ocurrieron 14 huelgas, la totalidad de ellas "provocadas por patrones de habla idish": Isaac Manis, Solmesky hnos., Pedro Zalsberg, Kabacoff, Schujman, Canelson, sólo por mencionar algunos. ${ }^{55}$ En general, todos los conflictos estuvieron motivados por la intención de los dueños de los talleres de rebajar los salarios, aumentar la jornada laboral y desconocer ciertas conquistas sindicales como la presencia del delegado.

Hacia 1927, se evidenció cierta reactivación económica en la rama, con un aumento en el número de afiliados y la presencia de 30 huelgas (en su mayoría en boliches, aunque algunos llegaban a emplear 30 obreros), que involucraron a alrededor de 377 obreros. ${ }^{56}$ Todas en general estuvieron nuevamente motivadas contra la rebaja o la falta de pago del salario y contra los despidos y suspensiones así como por el reconocimiento de la organización sindical; los resultados fueron, en varios casos, positivos para los trabajadores mientras que en una minoría fueron adversos. En aquel momento, se consignaban 190

\footnotetext{
50 “Por las fábricas y talleres”, Acción Obrera, núm. 44, agosto 1928.

51 “Hemos venido a menos", Acción Obrera, núm. 17, septiembre 1925.

52 "El sindicato del mueble realizó una importante reunión”, La Internacional, 1/12/1928.

53 "Nos hemos venido a menos", Acción Obrera, núm. 17, septiembre 1925.

54 “El trabajo extraordinario origina perjuicios”, Acción Obrera, núm. 23, mayo 1926; "Las 'changas' y ciertos compañeros lustradores", Acción Obrera, núm. 27, octubre 1926.

55 "Informe de Secretaría", Acción Obrera, núm. 27, octubre 1926; "Huelgas solucionadas", Acción Obrera, núm. 29, diciembre 1926.

56 "Actividades generales de la CA", Acción Obrera, núm. 33, julio 1927; "Resumen de las actividades más salientes de la CA en el $2^{\circ}$ semestre de 1927”, Acción Obrera, núm. 38, enero 1928.
} 
talleres organizados, es decir, con delegados que respondían en mayor o menor medida al organismo sindical. $^{57}$

En 1928, los conflictos asumieron una tónica similar al año precedente, con más de una veintena de episodios acaecidos en talleres de pequeñas dimensiones, con la excepción de las huelgas en el taller de Burgio y en el de Stein, ambas involucrando más de 40 obreros cada una y, a fin de año, una huelga de ocho días en la importante fábrica Nordiska, contra el despido de un delegado. ${ }^{58}$ En síntesis, si tuviéramos que resumir la conflictividad laboral entre 1926 y 1928, los hechos reseñados no dejaban de ser episodios menores que, no obstante, si se los alinea con cierta perspectiva histórica, se podría aseverar que formaban parte de una progresión ascendente que eclosionaría en 1929-1930.

\section{Las huelgas de 1929 y 1930}

En este último apartado, nos dedicaremos a reseñar las huelgas que sucedieron entre 1929 y 1930, cuya duración y profundidad marcaron el comienzo de una nueva etapa en la organización de los trabajadores de la industria del mueble. Como veremos, la dinámica que terminaron adoptando estas luchas derivó en un cambio en la conducción sindical e implicó un replanteo del conjunto de las formas de organización en la rama.

En marzo de 1929, se lanzaron a la lucha los trabajadores de la empresa sueca Nordiska (190 obreros), una de las fábricas de muebles más importantes del país. ${ }^{59}$ En este taller, las fricciones con la gerencia venían de hacía varios meses, motivando distintas acciones del personal. En esta ocasión, los obreros se vieron forzados a declarar la huelga para hacer echar a un contratista ${ }^{60} \mathrm{y}$ ante la negativa patronal a proveer las herramientas chicas, una vieja conquista extendida en muchos establecimientos y que Nordiska, para liquidar la organización sindical, había decidido reemplazar por el pago de diez centavos diarios. Asimismo, en virtud de su preeminente lugar en la asociación de patrones muebleros, incentivó a otras empresas a tomar la misma actitud.

De esta forma, el 22 de marzo comenzó el paro de actividades en Nordiska y rápidamente se contagió a las casas Sage y Verga hnos, dos importantes mueblerías. Una crónica resaltaba que la empresa había invertido una alta suma en la compra de "maquinarias de última invención para acelerar y simplificar la producción hasta un grado

\footnotetext{
57 "Efectivos del sindicato", Acción Obrera, núm. 33, julio 1927.

58 "Resumen de las huelgas", Acción Obrera, julio 1928; "Dos conflictos de los obreros del mueble", La Internacional, 3/11/1928; "Huelgas producidas durante el segundo semestre del año pasado", Acción Obrera, febrero 1929.

59 "El conflicto en el Taller Nordiska", Acción Obrera, abril 1929.

${ }^{60}$ Los contratistas eran una figura presente en algunas pocas fábricas de muebles; podían adoptar dos formas: como un individuo en el lugar de trabajo, generalmente a cargo de una sección particular, que se encargaba de seleccionar y proveer mano de obra; o, más común, la forma de una producción "descentralizada" realizada en un boliche para una empresa más grande. Ambas modalidades facilitaban a las patronales resolver el problema del control sindical sobre la bolsa de trabajo.
} 
imposible de superar en la actualidad" por lo que se confirmaba el carácter reactivo de la maniobra de la empresa para con la organización sindical. ${ }^{61}$

La huelga en el taller de Verga duró solo unos días y rápidamente los dueños decidieron volver a proveer las herramientas, quebrando el acuerdo de la sociedad patronal. ${ }^{62}$ En la inglesa Sage, en cambio, el paro comenzó el 4 de abril y se prolongó durante meses, puesto que hacía ocho años que este personal recibía sus insumos. ${ }^{63}$ A la medida se acabó por sumar también el 12 de abril el personal de la destacada casa Thompson (en aquel momento, en número de 200) ya que, si bien en este lugar no contaban con instrumentos chicos brindados por la empresa, los obreros se negaron por solidaridad a realizar los trabajos inconclusos enviados desde Nordiska así como también rechazaron los diez centavos. ${ }^{64}$ Idéntica actitud adoptaron los obreros del taller Caroselli. ${ }^{65}$ A esta altura, las luchas desatadas en tres de las principales empresas de muebles (Nordiska, Sage y Thompson) involucraban a 700 obreros.

En el desarrollo de estos conflictos, se dejaron entrever nuevamente las tensiones entre sindicalistas y comunistas. A las pocas semanas de comenzada la huelga, el PC, a través de la voz de Hernández, denunciaba a los sindicalistas en la asamblea por querer negociar la salida del conflicto de forma inconsulta a los trabajadores a través de una mediación con la gerencia de Thompson. ${ }^{66}$ En mayo, frente a las gestiones sin resultado promovidas por la CA sindicalista frente a las empresas y el ministerio de Hacienda, los comunistas llamaron a constituir un "Comité de ayuda y acción" para "acelerar el triunfo" de los huelguistas, realizando mítines periódicos en toda la ciudad. ${ }^{67}$ El comité estaba formado por Hernandez, Landan, Buyoltes, Feigel, Toporosi, Maguin, Sommi, Malamud y Fossa. En el mes de julio, luego de una marcha realizada desde plaza Once a Congreso, la policía prohibió estos actos callejeros por "incitar a la violencia". ${ }^{8}$ A los seis meses, los comunistas denunciaban que lo único que hacían la conducción sindical y la Unión Sindical Argentina (USA) era juntar cuotas de solidaridad. ${ }^{69}$

Producto en parte de estas disensiones y en otro plano a causa también del poderío de las empresas, el paro se prolongó durante meses y acabó con un magro resultado para los trabajadores, pese a que estuvo rodeado por enormes muestras de solidaridad, tanto del gremio como de otros sindicatos del país y que, por sobre todo, los personales en huelga se mantuvieron homogéneos en torno a la medida. Mediante circulares y cartas a los domicilios particulares, las empresas trataron de intimar a los obreros para presentarse a

\footnotetext{
61 "El conflicto en el Taller Nordiska", Acción Obrera, abril 1929.

62 "Triunfo de la huelga en la casa Verga", La Vanguardia, 10/4/1929.

63 "Nuestras luchas con las casas Fred Sage y cía., Nordiska Companiet y Thompson Muebles Ltd.", Acción Obrera, agosto-septiembre 1929.

64 "Las luchas del proletariado de la madera", La Internacional, 4/4/1929.

65 “Triunfo en el taller Caroselli”, Acción Obrera, núm. 51, abril 1929.

66 “Crónica de la asamblea del 12 de abril”, Acción Obrera, núm. 51, abril 1929.

67 "Se ha creado un comité de acción y ayuda a los obreros de la madera", La Internacional, 11/5/1929.

68 "La policía prohíbe los actos del Grupo Rojo de la Madera”, La Internacional, 13/7/1929.

69 "La huelga en la industria del mueble", La Internacional, 12/10/1929.
} 
trabajar aunque de forma infructuosa; incluso, llegaron a enviar matones. ${ }^{70}$ La policía, por su parte, detenía a los huelguistas que vigilaban talleres y obras. ${ }^{71}$ En uno de estos episodios, el obrero Domingo Carnevale hirió de bala al gerente de Sage, Harold Taylor. Perseguido por la policía, Carnevale se subió a un taxi y, en medio de los disparos, el chauffeur murió. ${ }^{72}$ Frente al deceso de José Piñeyro y bajo una intensa agitación del PC y los grupos que "orbitaban" a su alrededor, los obreros del mueble declararon el lunes 21 la huelga general -a pesar de la negativa de la CA sindicalista- y marcharon hasta el cementerio. ${ }^{73}$ Según la crónica comunista, en los barrios de Villa Crespo, La Paternal, Caballito y Palermo, la mayoría de los obreros pararon. ${ }^{74}$ Podría afirmarse que se trataba de los primeros episodios de un conflicto de más amplio alcance.

En este punto, cabe señalar que el Grupo Rojo venía interviniendo, desde fines de 1928, bajo el imperativo de desenvolver una movilización de carácter general por las reivindicaciones de todos los gremios en madera. Así, luego de los conflictos que describimos más arriba, el Grupo Rojo llamó a constituir el "Comité de Unidad Clasista de los Obreros de la Madera". ${ }^{75}$ La reunión aprobó un manifiesto, un programa y la creación de una comisión integrada por 19 obreros de las distintas ramas, estableciendo que el comité “...luchará para preparar la huelga general, para organizar el movimiento por las reivindicaciones del gremio..."; entre los puntos del programa, figuraban la jornada de siete horas y la unidad de los tres gremios. ${ }^{76}$ Es significativo indicar que, por lo menos hasta 1928 inclusive, el Grupo Rojo estaba constituido por fracciones pertenecientes a distintas tendencias por fuera del PC, como los anarco-aliancistas y los sindicalistas "rojos". 77

De esta manera, la confrontación en el gremio maderero se replicó a los pocos meses, cuando en mayo de 1930 el PC expuso su voluntad de radicalización de las luchas y sostuvo una huelga general de tres semanas contra todo el arco patronal. Los comunistas se venían preparando y fogoneaban los ánimos de los trabajadores para ir hacia un combate frontal, actuando según la orientación estratégica de "clase contra clase" (Camarero, 2007a). Este nuevo rumbo caracterizaba el derrumbe inminente del capitalismo y, por lo tanto, todo el discurso y las prácticas fueron ganadas por la "urgencia" revolucionaria. En el campo sindical, la línea sectaria de "clase contra clase" implicó que los comunistas valoraran positivamente a las organizaciones gremiales sólo en tanto fueran clasistas y revolucionarias, lo cual condujo a constituir sindicatos "rojos", es decir, propios o

\footnotetext{
70 “'Obreros del mueble”, La Vanguardia, 24/4/1929.

71 "La huelga de los obreros del mueble", La Internacional, 1/5/1929.

72 "A propósito de un hecho sangriento en el conflicto que nuestro sindicato sostiene con las empresas Nordiska, Sage y Thompson”, Acción Obrera, noviembre 1929.

73 “A pesar de los dirigentes, el proletariado de la madera fue a la huelga", La Internacional, 26/10/1929.

74 "Los obreros respondieron al llamado del grupo rojo contra la pasividad reformista", La Internacional, 26/10/1929.

75 “A los obreros de la Madera organizados y no organizados”, La Internacional, 16/11/1929.

76 "El sábado se ha constituido el Comité Pro Unidad Clasista de los Obreros de la Madera", La Internacional, 30/11/1929.

77 "Proposición unionista a varios camaradas que se separaron", La Internacional, 28/7/1928; "Importante asamblea general del Grupo Rojo de la Industria del Mueble", La Internacional, 27/10/1928. En esta se dejaba constancia que habría libertad para las distintas fracciones, sin que dominara ningún partido.
} 
exclusivamente controlados por el partido, a romper estructuras gremiales unitarias y a escindir a los sindicatos que dirigían de las centrales obreras existentes, "reformistas". Las organizaciones sindicales dirigidas o influenciadas por el PC se agruparon en un organismo llamado Comité de Unidad Sindical Clasista (CUSC), que virtualmente se constituyó en una cuarta central (Camarero, 2007a).

Situados desde esta perspectiva, apelaron a un choque directo de la clase obrera contra los empresarios, la dirección sindicalista del gremio y el aparato estatal. Para cumplimentar este objetivo, se dieron la tarea de realizar varias asambleas en los talleres y en los barrios que concentraban la mayor cantidad de establecimientos (Villa Crespo, La Paternal, sobre todo), abordando las salidas de los talleres y mediante un minucioso trabajo de afiliación al sindicato a través de sus locales partidarios. Cuando desde la conducción sindicalista se prohibió el flujo de nuevos obreros a la organización y se desalentaron los llamados a la lucha, el PC desencadenó un conflicto de vastas dimensiones.

La lucha comenzó con dos asambleas multitudinarias, convocadas desde el flamante "Comité Pro Unidad", logrando reagrupar a prácticamente la totalidad del gremio. Desde esa tribuna, se hizo un llamado a la huelga general en toda la industria y se plantearon una serie de reivindicaciones laborales. Eran las reuniones obreras más numerosas del período. De modo astuto, el comité hizo aprobar la propuesta de postergar el inicio del paro, para que la dirección sindicalista del SOIM se sumara al proceso. Sin embargo, cuando sesionaba la segunda asamblea en paralelo a las estructuras sindicales "habituales", la conducción sindicalista decidió expulsar a todos los integrantes del comité. ${ }^{78}$

El PC, entonces, decidió profundizar la medida y convocó a otra asamblea para el 23 de mayo, en el salón "Augusteo", que resultó aún más importante que la anterior, nucleando unos 3.000 obreros, que luego de debatir varias horas (con muchos extranjeros que intervenían en sus idiomas), aprobaron la propuesta del organismo del Comité de Unidad Sindical Clasista (CUSC) para comenzar el cese general de actividades y conformar un "comité de huelga". El lunes 26 se presentaron las reivindicaciones a los patrones y la respuesta empresarial fue negativa. El martes 27, una manifestación obrera ganó las calles de La Paternal, Villa Crespo y el centro de la ciudad y concluyó con un acto en la plaza Once, donde se vivó la inminente huelga. Con la dirección del sindicato del mueble en contra, el paro empezó formalmente el miércoles 28, adhiriéndose unos 4.000 trabajadores y, al día siguiente, sumándose otros 1.000 , o sea que, al segundo día, la huelga ya abarcaba a más de la mitad de los empleados del sector en la ciudad de Buenos Aires.

La huelga general maderera de 1930 tuvo un desarrollo violento desde el principio. Dos días antes de iniciarse, la policía comenzó con la política de intervención en los locales. Fueron allanadas las sedes del "Comité Pro Unidad Clasista de los Obreros de la Madera" de La Paternal, del PC de Villa Crespo y de Avellaneda, y del sindicato de sastres, entre otras; la mayoría de estos domicilios fueron clausurados y detenidos centenares de huelguistas y miembros del partido. Policías a caballo y agentes de investigaciones vigilaban los talleres. En los primeros días, tres obreros resultaron heridos por balas

\footnotetext{
78 "La gran huelga de los obreros de la madera en Buenos Aires", El Trabajador Latinoamericano, año II,
} núm.32-33, junio-julio de 1930. 
policiales y por los matones que aportaron las empresas. Las tácticas desplegadas por los comunistas también fueron brutales; activistas armados apalearon a muchos rompehuelgas con todo tipo de artefactos. ${ }^{79}$

El conflicto fue cubierto por la prensa sólo para narrar los hechos violentos y se lo presentó como una "huelga política provocada por el PC y los judíos", reclamándose la expulsión de los extranjeros huelguistas. La propia dirección de la USA no se privó de hacer uso de la xenofobia para separar a los obreros sindicalizados de los "agitadores foráneos" y las declaraciones del secretario general, Adán Ibáñez, se cimentaban en un prejuicio nacionalista y antisemita. Luego de aclarar que ni la USA ni el Sindicato del Mueble tenían "cuestiones" con el taller de Lapidus y Smud (uno de los afectados), el secretario afirmó que: "Los obreros que han actuado en la incidencia responden al Comité Clasista del PC (...) Probablemente los obreros en conflicto tendrán razón. La mayoría de los afiliados al comité Clasista Comunista son inmigrantes con poco tiempo de radicación en el país. Trabajan por dos o tres pesos diarios.". ${ }^{80}$ En la misma dirección apuntaron algunos diarios, señalando el carácter "extranjero" y "antinacional" de la agitación huelguística: "Dos mueblerías fueron asaltadas en el día de ayer, de una manera espectacular por individuos armados de revólveres, pistolas, cachiporras y palos. Y por añadidura, la enorme mayoría de estos sujetos son de nacionalidad extranjera y algunos ni siquiera hablan el idioma nacional, vale decir que, como en el caso de la Migdal [en esas semanas, el caso de un prostíbulo regenteado por cafishios polacos había generado una gran conmoción pública], son sujetos indeseables que vienen a introducir la intranquilidad y el desorden en un país que les ha brindado amplia y generosa hospitalidad." ${ }^{81}$

En los días posteriores a estos enfrentamientos, una feroz represión se abatió sobre los activistas y militantes, los locales del comunismo fueron asaltados por tropas policiales (en particular, el local cercano al establecimiento Lapidus, ubicado en Gurruchaga 770) y los cuadros gremiales del PC fueron detenidos, entre ellos, Aurelio Hernandez. ${ }^{82}$ A la semana de iniciado el conflicto, los detenidos eran unos 900, la mayoría en la cárcel de Villa Devoto. El PC denunció maltratos sobre los presos, que decidieron realizar una huelga de hambre, y fueron respaldados desde afuera del presidio por una manifestación de sus mujeres, que también resultaron detenidas.

El 6 de junio, el Comité Pro Unidad Clasista de los Obreros de la Madera realizó una nueva asamblea en medio de un clima tenso; aún había más de 500 encarcelados. Desde la tribuna, los comunistas repudiaron al sindicato del mueble, por no haberse sumado al conflicto ni haberse solidarizado con los presos y plantearon que era hora de romper con el gremio existente y fundar otro con un contenido "clasista". El comité de huelga adhirió a esa propuesta y convocó a una asamblea general para el 9 de junio. Ese día, unos 2.500 trabajadores votaron una resolución que disolvía el Comité Pro Unidad Clasista de los Obreros de la Madera y dejaba constituido el Sindicato Unitario de Obreros de la Madera

\footnotetext{
79 "El Sindicato de Obreros de la Industria del Mueble se reunirá esta noche”, Crítica, 6/6/1930.

80 "Habla el secretario de la USA", Crítica, 5/6/1930.

81 "Los carpinteros huelguistas asaltaron dos mueblerías", Crítica, 6/6/1930.

82 "Fue aprehendido un conocido agitador", El mundo, 12/6/1930.
} 
(SUOM). Surgió, de esta forma, uno de los sindicatos de industria más importantes del país en los años siguientes, abriendo una nueva etapa para la organización de los trabajadores del mueble.

\section{Conclusiones}

A modo de cierre, se distinguirán cuatro aspectos nodales que atravesaron el período 1915-1930. En primer término, describimos las características fundamentales del sector maderero y la morfología específica que presentaba el proceso de trabajo, semejante al de un conjunto de artesanos puestos a producir en un taller o fábrica en un estadio de desarrollo de cooperación simple, con una escasa división del trabajo, antes que una configuración propia de la gran industria capitalista, con un alto grado de mecanización. Para poner en conexión la fisonomía productiva de la rama con las vías que asumió la organización gremial en los lugares de trabajo, nos valimos del concepto de "autonomía artesanal", refiriéndonos a las formas concretas de contralor obrero en los talleres tales como la tarjeta sindical o el delegado. Así, el trabajo calificado (skilled work) resultó el camino principal sobre el cual se estructuró la organización, derivando todo un conjunto de peculiaridades que informaron las luchas y la conciencia obrera. En este plano, la corriente que mejor "interpretó" estas peculiaridades en los términos de una acción sindical sostenida en el tiempo fue el sindicalismo.

En segundo lugar, analizamos los primeros indicios de una paulatina modernización de la industria, fenómeno observable hacia 1926 en los establecimientos muebleros más importantes. En este punto, cabe señalar que la aplicación efectiva de las nuevas técnicas y formas de producción dependió de la capacidad de los dueños de los talleres por imponer una nueva relación de fuerzas dentro de los establecimientos e implicó, al mismo tiempo, una relativa descalificación del obrero. A su vez, se constató que la modernización capitalista de la rama redundó en una pérdida del control sindical sobre los talleres a la par de un decrecimiento de la "autonomía artesanal", base de la organización entre estos trabajadores. De esta forma, durante esta etapa se replantearon las formas de estructuración sindical y sus límites.

Como un tercer aspecto ligado a lo anterior, el estudio sobre la conflictividad laboral permitió identificar tres períodos diferenciados: 1916-1921; 1921-1924; 1924-1930. Cada uno de ellos presentó una dinámica específica de luchas, en torno a reivindicaciones variables según el estadio de desarrollo de la rama así como de acuerdo a las distintas lecturas que formularon las corrientes de izquierda sobre este proceso de industrialización creciente aunque incipiente. La primera etapa (1916-1921), signada por el auge huelguístico y el alza de la movilización obrera, buscó establecer un conjunto de reivindicaciones y derechos dentro de los lugares de trabajo. La segunda fase (1921-1924), englobó años de relativo estancamiento y desmovilización de los trabajadores, generándose un proceso de desestructuración de la organización sindical que motivó cierto retroceso en varias de las conquistas obtenidas en los años previos; durante esta etapa, las luchas fueron pocas y asumieron en general un carácter defensivo sobre derechos percibidos como 
"legítimos". El último período (1924-1930) estuvo condicionado por esta relativa desorganización del colectivo obrero y, en esta dirección, se constató un nivel de actividad huelguística y de conflictos laborales mínimo, si bien enmarcado en una tendencia creciente hacia el final de la década.

Como un cuarto y último aspecto, los años bajo estudio visibilizaron la disputa entre sindicalistas y comunistas por el control del gremio. Así, podemos concluir en que, de un lado, los cuadros del PC tuvieron una comprensión más "realista" sobre las transformaciones que estaban ocurriendo dentro del proceso de trabajo y, del otro costado, en sintonía con esta caracterización trabajaron en el sentido de mutar las formas de organización sindical. De este modo, la excluyente línea estratégica de "clase contra clase" permitió a los comunistas reagrupar a los trabajadores por la base en un polo de lucha común que, a la postre, terminó por desplazar a los sindicalistas de la conducción del SOIM. Este desplazamiento, en última instancia, podría comprenderse como producto de la incapacidad de los sindicalistas por acomodarse al nuevo marco estructural que fijaba el desarrollo de la industrialización.

En síntesis, muchas de las tendencias y fenómenos apuntados continuaron actuando en las décadas de 1930 y 1940, si bien bajo otras formas y modalidades y expresando otros contenidos. A lo largo de los años subsiguientes, queda por ver cuáles fueron sus continuidades y rupturas y cómo prosiguió el camino de la organización sindical de los trabajadores madereros.

\section{Bibliografía}

-Aquino, Cristian (2015), "Bajo la influencia de la Revolución Rusa. La Federación de Agrupaciones Sindicalistas Revolucionarias a través de La Batalla Sindicalista, 1920-1923", Archivos de historia del movimiento obrero y la izquierda, año IV, núm. 7, septiembre, Buenos Aires, págs. 123-142.

-Avni, Haim (1983), Argentina y la historia de la inmigración judía 1810-1950. Buenos AiresJerusalén: Universitaria Magnes-Universidad Hebrea de Jerusalén.

-Belini, Claudio y Korol, Juan Carlos (2012), Historia económica de la Argentina en el siglo XX. Buenos Aires: Siglo XXI.

-Bertolo, Maricel (1993), Una propuesta gremial alternativa: el sindicalismo revolucionario (19041916). Buenos Aires: Centro Editor de América Latina.

-Bilsky, Edgardo (2011) [ed. orig. 1984], La semana trágica. Buenos Aires: Razón y revolución.

-Camarero, Hernán (2015), "El Partido Socialista de la Argentina y sus espinosas relaciones con el movimiento obrero: un análisis del surgimiento y disolución del Comité de Propaganda Gremial, 1914-1917”, Izquierdas, núm. 22, Santiago de Chile.

-- (2007b), "Consideraciones sobre la historia social de la Argentina urbana en las décadas de 1920 y 1930: clase obrera y sectores populares", .Nuevo Topo. Revista de historia y pensamiento crítico, núm. 4 , septiembre-octubre.

(2007a), A la conquista de la clase obrera. Los comunistas y el mundo del trabajo en la Argentina, 1920-1935. Buenos Aires: Siglo XXI Iberoamericana. 
-Camarero, Hernán y Ceruso, Diego (2015), "Una historia del sindicato de la madera: organización gremial e influencia de la izquierda en las luchas obreras, Buenos Aires, 1917-1943”, el@tina. Revista electrónica de estudios latinoamericanos, vol. 13, núm. 50.

-Camarero, Hernán y Herrera, Carlos (2005), El Partido Socialista en Argentina. Sociedad, política e ideas a través de un siglo. Buenos Aires: Prometeo.

-Caruso, Laura (2016), Embarcados. Los trabajadores marítimos y la vida a bordo: sindicato, empresas y Estado en el puerto de Buenos Aires, 1889-1921. Buenos Aires: Colección Archivos núm.5, Imago Mundi.

-Ceruso, Diego (2015), La izquierda en la fábrica. La militancia obrera industrial en el lugar de trabajo, 1916-1943. Buenos Aires: Colección Archivos núm. 4, Imago Mundi.

-Del Campo, Hugo (1983), Sindicalismo y peronismo. Buenos Aires: CLACSO.

-Díaz Alejandro, Carlos (1970), Ensayos sobre la historia económica argentina. Buenos Aires: Amorrortu.

-Doeswijk, Andreas (2013), Los anarco-bolcheviques rioplatenses (1917-1930). Buenos Aires: Cedinci.

-Dorfman, Adolfo (1970), Historia de la industria argentina. Buenos Aires: Solar/Hachette.

-Facciolo, Ana María (1981), "Crecimiento industrial, expansión metropolitana y calidad de vida.

El asentamiento obrero en la región metropolitana de Buenos Aires desde principios de siglo",

Desarrollo Económico, núm. 80, Buenos Aires.

-Falcón, Ricardo (1987), "Izquierdas, régimen político, cuestión étnica y cuestión social (18901912)", Anuario Escuela de Historia, núm. 12, Rosario.

-Gerchunoff, Pablo y Llach, Lucas (2010) [ed. orig. 1998], El ciclo de la ilusión y el

desencanto. Un siglo de políticas económicas argentinas. Buenos Aires: Ariel.

-Gutman, Margarita y Hardoy, Jorge Enrique (2007), Buenos Aires 1536-2006: historia urbana del área metropolitana. Buenos Aires: Infinito.

-Horowitz, Joel (2015), El radicalismo y el movimiento popular (1916-1930). Buenos Aires: Edhasa.

-Iñigo Carrera, Juan (2007), La formación económica de la sociedad argentina. Buenos Aires: Imago Mundi.

-Iñigo Carrera, Nicolás (2012) [ed. orig. 2000], La estrategia de la clase obrera, 1936. Buenos Aires: Imago Mundi.

-Jmelnizky, Adrián y Erdei, Ezequiel (2005), La población judía de Buenos Aires. Buenos Aires: Joint-AMIA.

-Kersffeld, Daniel (2012), Rusos y rojos. Judíos comunistas en los tiempos de la Comintern. Buenos Aires: Capital Intelectual.

-Lobato, Mirta Zaida (2009), La prensa obrera. Buenos Aires y Montevideo, 1890-1958. Buenos Aires: Edhasa.

-Marotta, Sebastián (1961), El movimiento sindical argentino. Su génesis y desarrollo, tomo II, Período 1907-1920. Buenos Aires: Ediciones Lacio.

--------- (1960), El movimiento sindical argentino. Su génesis y desarrollo, tomo I, Período 1857-1907. Buenos Aires: Ediciones Lacio.

-Montgomery, David (1979), Workers' control in America: studies in the history of work, technology, and labor struggles. Cambridge: Cambridge University Press.

-Palacio, Juan Manuel (2000), "La antesala de lo peor: la economía argentina entre 1914 y 1930", Nueva Historia Argentina, vol. 6: Democracia, conflicto social y renovación de ideas (1916-1930). Buenos Aires: Sudamericana. 
-Pittaluga, Roberto (2015), Soviets en Buenos Aires. La izquierda de la Argentina ante la revolución en Rusia. Buenos Aires: Prometeo.

-Rapoport, Mario et. al. (2006), Historia económica, política y social de la Argentina (1880-2003). Buenos Aires: Ariel.

-Rocchi, Fernando (2005), Chimneys in the desert: industrialization in Argentina during the export boom years, 1870-1930. Stanford: Stanford University Press.

-Rock, David (1977), El radicalismo argentino, 1890-1930. Buenos Aires: Amorrortu.

-Romero, Luis Alberto y Gutiérrez, Leandro (1995), Sectores populares, cultura y política. Buenos Aires en la entreguerra. Buenos Aires: Sudamericana.

-Schvarzer, Jorge (1996), La industria que supimos conseguir. Buenos Aires: Planeta.

-Suriano, Juan (2001), Anarquistas. Cultura y política libertaria en Buenos Aires, 1890-1910. Buenos Aires: Manantial.

-Villanueva, Javier (1972), "El origen de la industrialización argentina", Desarrollo Económico, núm. 47, octubre-diciembre, Buenos Aires.

-Visacovsky, Nerina (2016), Argentinos, judios y camaradas. Tras la utopía socialista. Buenos Aires: Biblos. 